\title{
Corporate social responsibility spending of commercial banks: determinants and consequence
}

\author{
Alhassan Musah \\ Faculty of Business and Social Sciences, Academic City University College, Ghana \\ Correspondence authoremail: alaye88@gmail.com/alhassan.musah@acity.edu.gh

\begin{tabular}{|l|l|l|l|l|}
\hline DOI: & Received: & Revised: & Accepted: & Published: \\
10.22437/ppd.v8i5.10507 & 18.09 .2020 & 11.11 .2020 & 20.12 .2020 & 31.12 .2020 \\
\hline
\end{tabular}

\begin{abstract}
The contribution of firms towards society in the form of corporate social responsibility has attracted significant concern for many stakeholders, especially among banks in Ghana. It is perceived that; banks especially do Corporate Social Responsibility just because they are the most profitable sector in Ghana. The study sort to examine the kind of relationship that exists between bank performance and CSR in Ghana. Also, to determine how bank size and profitability and it's listing status and foreign ownership influence CSR spending in Ghana. The study sampled 24 commercial banks over seven years from 2010 to 2016. The study analyzed data using statistical tools such as descriptive statistics, correlation analysis, and panel regression analysis. The study found out that engaging in CSR activities increases banks' profitability in Ghana, especially for ROE. Besides, the study concluded that bigger and larger banks are more profitable than small companies, so they are more involved in CSR activities. The study also investigated whether foreign ownership and the listing status of banks influence CSR spending. On this aspect, the study found out that banks' listing status influences CSR spending, but foreign ownership does not. The result implies that listed banks are more public and faces more social pressure hence they spend more on CSR to legitimize their operations.
\end{abstract}

Keywords: CSR spending, Commercial banks, Performance, Ghana.

JEL Classsification: G30, G31, M14, M41

\section{INTRODUCTION}

Research has shown that banks in Ghana view CSR as a strategic tool for competitive advantage (Ofori, Nyuur \& Darko, 2014; Islam et al., 2013) and profitability and sustainability. Customers are becoming more environmentally concerned; hence, banks must ensure sustainable development through corporate social responsibility through which the organization will have been ethical (Bhagawan \& Mukhopadhyay, 2018; Almamun et al., 2013). The banking sector is one of the most competitive sectors since its liberalization in the 1980s that allowed private sector participation (Musah et al., 2019). There is also a growing non-bank financial institution providing similar services and competing with commercial banks (Ofori et al., 2014). Banks have been compelled by the increased competition to adopt innovative strategies to attract and retain customers as the banks' failure to give customers a reason to stay will allow competitors to give them a reason to leave. 
Corporate social responsibility has attracted researchers' attention in the last few centuries amid concerns over climate change (Coffie et al., 2018; Welbeck et al., 2017; Ofori et al., 2014). A literature review has shown that these studies have been skewed towards developed and western countries and emerging markets with less studies in developing countries (Fifka, 2013). Fifka (2013) further argued that the need for corporate social responsibility is more pronounced in developing countries than developed countries, but the reality is the opposite (Coffie et al., 2018; Hassn, 2014).

The higher proportion of multinational companies and banks in developing countries and the gap in the provision of social and economic amenities in developing countries make corporate social responsibility more important in developing countries than in developed countries. The legitimacy theory assumes that firms engage in corporate social responsibility to legitimize their operations and also as a means of public relations (Coffie et al., 2018; Aboagye-Otchere et al., 2020). This suggests that the firm's CSR engagement is not geared towards improving their financial performance, but to help banks look good in their major stakeholders' eyes and gain legitimacy. This notwithstanding, modern organizations, including banks, use CSR as a corporate strategy to gain a competitive advantage, attract and retain customers, and improve their brand, translating into improved financial performance (Ofori et al., 2014).

The need to evaluate Ghanaian commercial banks' social responsiveness to the citizen through their corporate social responsibility is premised on some perceptions about the banking industry in Ghana. The banking sector in Ghana has been the most profitable over the years and is perceived to make an abnormal profit, hence giving back to society. Secondly, the service sector has been the largest contributor to Ghana's gross domestic product in the last few years, with the banking sector dominating the sector in terms of growth and required to contribute more to society (Musah et al., 2019). Finally, commercial banks enjoy more visibility in terms of the beauty of their structures. The higher branch numbers and the continuous media attention on the sector increase social pressure on these banks to be socially responsible. According to Connett et al. (2014), banks globally take corporate social responsibility more seriously than other non-bank firms.

On the global stage, studies that have examined the effect of CSR and financial performance have been well researched in other jurisdiction but have produced mixed results (Bhagawan and Mukhopadhyay, 2018; Connett et al. 2014; Lee et al. 2013; Islam, 2013; Samina, 2012; Garcia-Castro et al. 2010; Griffin \& Walsh, 2003). For instance, Bhagawan and Mukhopadhyay (2018) reported a positive association between CSR and firm performance, whiles Connett et al. (2014) reported a negative association between CSR and firm performance. Moreover, CSR studies have focused mainly on the extractive sector and manufacturing companies because of the consequence of their operations on the environment, with little on the banking sector (Aboagye-Otchere et al., 2020).

The few studies on CSR and bank financial performance have also produced mixed results (Fijałkowska et al., 2017; Ofori et al., 2014; Wu \& Shen, 2013; Samina, 2012; Soana, 2011). For instance, while Ofori et al. (2014) and Wu \& Shen (2013) reported a positive association between CSR and bank performance, Fijałkowska et al. (2017) reported no significant association between CSR and bank performance. The contrary evidence from previous studies makes this study very important and the fact that banks in Ghana compete over brand image to attract and retain customers.

Several studies have examined CSR activities, reporting, and disclosures in Ghana but little on the effect of CSR spending and financial performance of firms or banks (Aboagye-Otchere et al., 2020; Coffie et al., 2018; Welbeck et al., 2017; Hinson et al., 2010; Rahaman et al., 2004). The only study that has examined the effect of CSR and 
financial performance is the study by Ofori et al. (2014), even though the study did not use CSR spending as a measure of CSR activities of banks in Ghana. Commercial Banks in Ghana have been known for their corporate social responsibility in various sectors of the economy. It is against this background that the research seeks to: 1) investigate the relationship between bank performance of Commercial Banks in Ghana and CSR activities; 2) find out to what degree does bank size and profitability influence CSR spending in Ghana; 3 ) to examine the influence of foreign ownership and listing status on CSR spending in Ghana of commercial banks

CSR studies have primarily used disclosures and reporting as a basis for measuring CSR of the selected institutions (Coffie et al., 2018; Abukari \& Abdul-Hamid, 2018). Few studies have relied on firm CSR spending to measure CSR activities (Islam, 2013). Few studies have also examined what drives firms' CSR spending, especially banks. The study simple wanted to understand why some banks spend more money on CSR than others to help drive the CSR conversation in the Ghanaian banking sector.

This study is based on the legitimacy theory, which argues that banks engage in CSR to legitimizes their activities, and hence no reward is expected. Legitimacy theory, therefore, does not anticipate a positive association between firm CSR spending and profitability. However, the theory expects that larger banks and foreign-owned banks, and perhaps listed banks, will spend more on CSR because of the degree of their exposure (Aboagye-Otchere et al., 2020; Coffie et al., 2018; Taskin, 2015). Banks with these characteristics suffer from higher public scrutiny, which compels them to respond through more CSR spending. Therefore, the study's general purpose is to examine the association between bank CSR spending and its profitability and examine bank-specific characteristics that drive its CSR spending in Ghana.

The study makes significant contributions to literature in terms of both theory and empirical analysis. First, the study is among the few studies that seek to understand why banks spend money for CSR purposes using their CSR expenditure. Second, the study relies on legitimacy theory to explain the relationship between CSR and profitability and determinants of CSR that have not been examined in the Ghanaian context. The study also extends previous studies on CSR in Ghana by using a more reliable CSR measure: CSR's amount. The study's result is also useful to policymakers, especially as Ghana is yet to develop a full policy on Ghana's firm CSR.

\section{LITERATURE REVIEW}

\section{Corporate social responsibility research in Ghana}

Several studies have been conducted on a different aspect of CSR in Ghana in different industries and sectors. Corporate social responsibility studies in Ghana have gained significant attention in the last decades with studies on firms' CSR activities, disclosures, and reporting, among others. Rahaman et al. (2004) examined social and environmental issues using the Volta River Authority as a case study and reported that CSR was motivated by stakeholder pressure. Ofori and Hinson (2007) looked at the CSR perspective of top firms in Ghana based on the top 100 firms' raking in Ghana. The study compared CSR of local firms and foreign-owned firms in Ghana and reported that CSR appreciation among the local firms was less than the foreign firms. The study also found that foreign firms engage in more CSR dimensions compared to local firms.

Hinson et al. (2010) focused on CSR reporting on the websites of commercial banks in Ghana. The study found that banks that have won CSR awards organized by the Ghana Bankers Association had lower reporting of their CSR activities on their website than 
those who have not won such awards. The result suggests that banks do not appreciate the importance of reporting on their website's CSR activities.

In a related study, Hinson \& Kodua (2012) focused on CSR activities of some selected foreign and local entities in Ghana. The study found that foreign firms' CSR activities are based on legal prescription, while local firms were based on discretionary motives. The study attributed the discretionary CSR by local Ghanaian firms to the cultural practice where those who have must provide help to the less privileged.

The study that is most related to the current study is the one by Ofori et al. (2014), where they examined CSR's effect on banks' financial performance in Ghana. The study relied on the mixed approach of data collection, including questionnaires and secondary data from the banks' financial statements. The study results showed a positive relationship between CSR activities and banks' financial performance and the fact that banks use CSR as a strategic tool to legitimize their operations. Other studies on CSR in Ghana focused on social and environmental disclosures with less attention to its financial performance impact (Aboagye-Otchere et al., 2020; Coffie et al., 2018; Mahmoud et al., 2017; Boateng \& Abdul-Hamid, 2017; Welbeck et al., 2017). Even though these studies examined CSR disclosures, they did not link it to the firms sampled's financial performance. Also, only two of the above studies focused on the banking sector in Ghana.

\section{The impact of CSR on bank performance}

Generally, many research works have gone into the study of the relationship between CSR and bank performance. According to Orlitzky et al., (2003), the overall empirical results have shown a positive relationship between CSR and business performance. Besides, Shen \& Chang (2009) revealed that firms with strong CSR environments perform much better across various financial scale (metrics) than their competitors with weaker CSR environment. Also, El Ghoul et al. (2011) research work revealed that firms with strong CSRs have lower operating risk, lower cost of equity, and higher overall firm valuation. Also, Cheng et al. (2014) posit that firms with better CSR have more investment opportunities and higher firm value due to easy access to capital liquidity from customers and stakeholders.

In research conducted by Bolton (2013) on the topic "CSR and bank performance and the risks for US banks" came up with complex salient findings. His work revealed a positive relationship between CSR and bank operations and profit/value of the firm. Aspects of his findings were, however, more pronounced in the largest banks and corporations. On the other hand, his findings also revealed a negative relationship banks' risk-taking and CSR environment, especially those aspects of the banks' CSR environment that are key to the banks' operating activities. Also, he revealed that those same aspects o the banks' CSR environment were negatively related to whether or not those US banks received Troubled Asset Relief Program (TARP) relief assistance to bail themselves during the 2008 global financial crisis. However, the overall result shows that improving CSR quality at banks might further improve individual banks and reduce the system of problematic risks associated with the banking sector.

Brian (2012) has also disclosed that even though enough works have been centered on specifics of CSR related issues, little has been done on CSR and Bank performance. A study by Islam et al. (2012) work studied the relationship between CSR and bank performance. Their work revealed a positive but insignificant relationship of CSR enhancing the operating performance of a sample of banks in Bangladesh.

Marcia et al. (2013) explored the extent to which commercial banks in the United States and determine if the banks' level of social responsibility has changed after the financial crisis and to determine if such CSR activities are being rewarded by way of 
improved financial. The study relied on secondary data from the financial statement of the banks. The study result showed that large banks have consistently shown strong interest in CSR over the study period, but that reduced after the financial crisis. The study also found that larger banks engaged more in CSR and that their CSR activities were positively associated with return on assets and return on equity. The larger banks also took steps to repair their damaged reputation due to their role in the financial crisis by continuously engaging in CSR.

A study by Sweeny (209) used structural equation modeling to determine CSR's effect on firms' financial performance. The study used primary data collected by administering questionnaires to the sampled SMEs and large firms used for the study. The study also complimented the questionnaire with structured interviews of top executives in the respective organizations. The study found that the organizations had integrated CSR activities into their operations and had also formalized it. However, the concept of CSR differed from SMEs to large organizations, and as such, the study found a correlation between CSR activities and firm size.

In a related study, Carmen-Pilar et al. (2011) examined CSR's effect on the short and long-term financial performance of entities listed on the Stoxx Europe 600 index and the Stoxx Europe sustainability index. The study results showed that entities' corporate social performance was positively associated with their return on equity. The study found that firms that invest more in being socially responsible are associated with improved financial performance in Europe, which justifies firms' need to be socially responsible in these countries. The study also found a positive association between corporate social performance and the return on equity of the same firms, but this was also associated with the country's development level.

Okiro et al. (2013) established the association between CSR activities and commercial banks' growth in Kenya. The study relied on primary data through the use of a questionnaire as the data collection instrument. The study found that banks used CSR as a means to attract and retain customers for their banks. The study also reported a positive coefficient between CSR investment and the growth of the banks sampled for the study. However, the association between CSR and growth was described as weak based on the correlation coefficient between the two variables. In a related study, Okoth (2012) reported a positive coefficient between CSR activities and large and medium-sized banks' financial performance but no significant association between CSR and small banks. In addition to the above, Mudugu \& Okafo (2016) study on Nigerian banks tested the relationship between CSR and firm performance of Nigerian banks. The study results showed that CSR activities were negatively associated with earnings per share and dividend per share but a positive association between CSR and return on capital employed.

Furthermore, Fijałkowska et al. 2017 studied CSR's effect on accounting data of sampled firms in Poland. The study found that even though the bank had invested in CSR activities over the study period, it did not reflect its bottom line. Finally, Bhagawan and Mukhopadhyay (2018), in their study based on a sample of Indian firms, found that CSR activities were positively associated with improved financial performance and firm value.

\section{Determinants of firm CSR spending}

Previous studies show that corporate social responsibility determinants in accounting literature have focused on disclosures with very little on factors that influence firm CSR spending (Coffie et al., 2018; Abukari \& Abdul-Hamid, 2018; Fifka, 2013). Several studies have found a positive and significant association between firm characteristics and CSR disclosures. Recent studies have revealed a few studies focusing 
on CSR expenditure and profitability and its potential determinants. The legitimacy theory argues that firm characteristics determine how firms respond to social pressure by engaging in CSR to legitimize their activities (Coffie et al., 2018; Hassn, 2014). This means that banks with high visibility, more profitable, and foreign-owned will likely spend more on CSR to legitimize their operations in Ghana. The analysis below is a few empirical studies that have examined some of these firm characteristics in other contexts.

Chauhan (2014) examined firm characteristics that determined corporate social responsibility spending. The study used a sample of 30 listed firms over six years from 2007 to 2012. The firm characteristics examined in the study include firm size, firm profitability, firm leverage, and firm sales. The study results showed that firm size, firm profitability, and firm sales significantly influence CSR expenditure.

Mamun et al. (2013) studied the determinants of CSR expenditure of commercial banks in Bangladesh over two years from 2011 to 2012. The study results showed that the number of branches, total investment, and numbers of employees significantly influence bank CSR spending in Bangladesh.

Ahmed \& Akter (2015) examined CSR's determinants by banks listed on the Dhaka Stock Exchange. The study measured bank CSR using their CSR spending. The regression results revealed that promotional expenditure and the number of branches significantly influenced bank CSR spending.

Samina (2012) examine the adherence of Islamic banks in Bangladesh to the prescribed form of CSR activities, which included examining the potential determinants of these banks' CSR spending. The study results showed a strong positive correlation between bank CSR expenditure and bank deposit, loan, and profitability.

Islam (2012) examined the impact of profitability on bank CSR expenditure, and the study also included variables such as firm size, return on equity, assets quality, and capital adequacy ratio. The study results revealed that firm size, asset quality and return on equity were positively associated with firm CSR expenditure. In contrast, the capital adequacy ratio was negatively associated with bank CSR expenditure.

\section{Hypothesis development}

Several studies have examined CSR's impact on the banking industry and firm performance, especially in developed countries. Most of these studies have reported a positive and significant association between CSR and bank profitability (Ofori et al. 2014). What is somewhat different in this study from previous studies is the measurement of CSR. Most studies rely on bank CSR performance, or index on CSR activities disclosed as a CSR measure and not necessarily focusing on the amount spent on CSR. That notwithstanding, the amount of money spent on CSR determines the bank's commitment towards CSR.

Previous studies have established a positive relationship between bank CSR and financial performance (Cornett et al., 2016 in U.S., Adeyanju, 2012; Ofori et al., 2014; Tafti et al., 2012; Weshah et al., 2012). In Taskin (2015), mixed relationships were found, while no relationship between CSR and financial performance was presented in Soana (2011). Based on the findings of previous studies, the study hypothesizes that:

H1: There is a positive and significant association between CSR spending and bank performance in Ghana measured by ROA and ROE.

Firm characteristics have been among the most research variables in terms of determinants of bank CSR activities. The majority of previous studies report a positive association between firm size and its CSR activities. Profitability has also been another firm characteristic that influences bank CSR activities. This study examines how bank 
size, bank profitability measured by ROA and ROE, foreign ownership of banks, and the banks' listing status.

Previous studies have reported a positive association between bank sizes, bank profitability, and bank CSR (Chauhan, 2014; Mamun et al., 2013; Samina, 2012; Islam, 2012). Foreign ownership and listing status have rather received little attention in the literature. Based on the legitimacy theory, foreign banks have greater legitimacy responsibility towards their communities and are expected to spend more in CSR to legitimize their operations. From the perspective of stakeholders' theory, the foreign bank has more stakeholders and is likely to face tougher regulations. They will have to use CSR to reduce those pressures. Based on these arguments, it is expected that there will be a positive association between foreign bank ownership and bank CSR spending/expenditure.

On the last variable listing status of commercial banks, it is expected that listed banks face a greater degree of pressure to legitimize their operations. This pressure from their numerous stakeholders and regulators will compel them to spend more on CSR in an attempt to legitimize their operations. This means that listed banks are expected to spend more in the area of CSR as compared to non-listed banks. Based on the above arguments, the following hypothesis can be drawn from the determinants of bank CSR spending in Ghana.

H2: There is a positive association between bank size and CSR Spending

H3: There is a positive association between bank profitability and CSR spending

H4: There is a positive association between foreign ownership of banks and CSR spending

H5: There is a positive association between the listed banks and CSR spending.

\section{METHODS}

The study is based on a quantitative research design and makes use of secondary data. Annual reports of some selected commercial banks were used for the study. Since the public would be interested in making an investment or buying shares in these firms, social information disclosed in their annual reports makes it easy to get a fair idea about the firms' affairs. Commercial banks operating in Ghana constitute the study population, and at the time of data collection, there were 33 licensed commercial banks by the Bank of Ghana.

The study adopted the panel data approach to improve the sample size since quantitative studies' quality and reliability depend largely on sample size. In a study by Stutely (2003), it was argued that the minimum sample size for quantitative analysis is 30. The sample selection from the licensed commercial banks was based on data availability, especially the extent to which the banks publish their financial statements and banks who have financial statements covering 2010 to 2016. The sample period covered 2010 to 2016, with 24 banks meeting the sample selection criteria.

The study adopted two empirical models to achieve the objectives of the study. The first model focused on the effect of CSR expenditure on banks' financial performance in Ghana, where banks' performance was represented by return on assets and return on equity. The second model focused on the determinants of bank CSR spending in Ghana.

The following panel regression models were adopted to examine the effect of CSR spending/expenditure on bank financial performance,

$$
\begin{aligned}
& R O A_{i t}=\beta_{0}+\beta_{1} \operatorname{CSREXP}_{i t}+\beta_{2} \operatorname{SIZE}_{i t}+\beta_{3} L_{I S T}+\beta_{4} O W N_{i t}+\varepsilon_{i t} \\
& R O E_{i t}=\beta_{0}+\beta_{1} \operatorname{CSREXP}_{i t}+\beta_{2} S I Z E_{i t}+\beta_{3} L I S T_{i t}+\beta_{4} O W N_{i t}+\varepsilon_{i t}
\end{aligned}
$$


The following panel regression model was also adopted to examine the determinants of banks CSR spending or expenditure in Ghana,

$$
\operatorname{CSREXP}_{i t}=\beta_{0}+\beta_{1} R O A_{i t}+\beta_{2} R O E_{i t}+\beta_{3} S I Z E_{i t}+\beta_{4} O W N_{i t}+\beta_{5} L I S T_{i t}+\varepsilon_{i t}
$$

Where

ROA (Return on Assets) = Profit before tax divided by Total Assets

ROE (Return on equity) = Profit after tax divided by Total equity

CSREXP $($ Corporate social responsibility expenditure $)=$ Natural logarithm of bank CSR expenditure

SIZE (Size of Commercial banks) = Natural logarithm of Total Assets

OWN (Foreign Ownership) = Dummy, 1 if the bank is a foreign bank, 0 otherwise

LIST (The listing status of commercial banks) = Dummy, 1 if a bank is listed on the Ghana Stock Exchange, 0 otherwise

\section{RESULTS AND DISCUSSION}

\section{Descriptive statistics}

The average return on assets for commercial banks over the study period is $3 \%$, with a minimum of negative $5 \%$ and a maximum of $12 \%$. The results are similar to Musah (2018) findings, whose study based on commercial banks in Ghana reported an average ROA of $3 \%$ but a maximum of $8.5 \%$. However, the average ROA is lower than that reported by Awunyo-Vitor (2012), who reported a 4.3\% average profit based on a sample of listed banks on the Ghana Stock Exchange. On the second measure of profitability, the average return to equity holders of commercial banks in Ghana averaged $15 \%$ with a minimum of negative $5 \%$ and a maximum of $51 \%$.

Table 1. Descriptive statistics

\begin{tabular}{lrrrr}
\hline Variable & Mean & Std. Dev & Min & Max \\
\hline ROA & 0.0297 & 0.0275 & -0.053 & 0.12 \\
ROE & 0.1518 & 0.3887 & -0.452 & 0.511 \\
CSR EXP & $1,463,533.97$ & 0.97345 & 2,000 & $5,000,000$ \\
OWN & 0.5892 & 0.4934 & 0 & 1 \\
SIZE & 9.0892 & 0.5834 & 7.8084 & 12.72336 \\
LIST & 0.3333 & 0.4728 & 0 & 1 \\
\hline
\end{tabular}

On the CSR spending of commercial banks in Ghana, the descriptive statistics reveals that commercial banks in Ghana spend an average of $\mathrm{GH} \phi 1,463,533.97$ over the study period. The bank with the highest spending on CSR was GH $\varnothing 5,000,000$, and the one with the least expenditure on CSR was $\mathrm{GH} \phi 2,000$. The results also revealed that $59 \%$ of commercial banks sampled for the study are foreign-owned, suggesting that foreign banks dominate Ghana's banking industry. Finally, the results show that a third $(33.33 \%)$ of the sampled commercial banks is listed on the Ghana Stock Exchange.

\section{Correlation analysis}

On the relationship between banks' CSR expenditure and profitability, two analyses are presented based on the two measures of profitability ROA and ROE whiles on the determinants of banks CSR spending. Only one correlation analysis is presented with CSREXP dependent variable. The results of the correlation analysis are presented in Tables 2, 3, 4 .

The correlation analysis presented in Table 2 shows a positive but statistically insignificant correlation between return on assets and bank CSR spending. The results suggest that an increase in bank CSR spending improve profitability even though the 
relationship is weak. This study is contrary to the findings of Bill (2012). Hotels in the communities mostly engaged in social initiatives just to be in harmony with the community's people. So they can be seen as part of the bigger family, which is the community and not because of how profitable CSR is to them.

Ansong (2017) found out that there existed an indirect effect of CSR on SMEs' financial performance through stakeholder engagement, which was also in agreement with the findings of Donaldson \& Preston, (1995) and Freeman, (1983). Nnachi \& Isu (2017) also concluded a significant relationship between corporate social responsibility expenditure and bank profitability in Nigeria. The result further shows a positive and significant correlation between a bank's size and its profitability. Also, foreign ownership has a positive and significant correlation with return on assets, just as banks' listing status positively correlates with return on assets. This finding is consistent with Musah (2018), which infers that the size of a company and some other factors are important determinants of profit. It draws the community's attention towards urging these big companies to be socially responsible. When this happens, more customers are attracted, which, in turn, increases profits.

Table 2. Correlation analysis between ROA and other independent variables

\begin{tabular}{llllll}
\hline & ROA & CSREXP & SIZE & OWN & LIST \\
\hline ROA & 1.00 & & & & \\
CSREXP & 0.0363 & 1.00 & & & \\
SIZE & $0.3085^{* * *}$ & 0.4732 & 1.00 & & \\
OWN & $0.2502^{* *}$ & -0.2294 & -0.0842 & 1.00 & \\
LIST & $0.1918^{*}$ & 0.2278 & 0.2808 & -0.1027 & 1.00 \\
\hline
\end{tabular}

(*** denote significant at 1\%, ** significant at 5\%, * significant at 10\% significance level)

The second correlation analysis in Table 3 shows a positive and significant correlation between bank CSR spending and return on equity. The result confirms the study's expectations and shows that bank spending in CSR improves profitability to equity holders. The control variable, bank size, foreign ownership, and banks' listing status were all positively correlated with return on equity even though only bank size is statistically significant. The results are contrary to Bowerman and Sharma (2016) findings, who found no significant association between CSR and financial performance of firms in the United Kingdom and Japan.

Table 3. Correlation analysis between ROE and other independent variables

\begin{tabular}{llllll}
\hline \multicolumn{1}{c}{ ROE } & CSREXP & SIZE & OWN & LIST \\
\hline ROE & 1.00 & & & & \\
CSREXP & $0.1593 * *$ & 1.00 & & & \\
SIZE & $0.2087 * * *$ & 0.4732 & 1.00 & & \\
OWN & 0.1146 & -0.2294 & -0.0842 & 1.00 & \\
LIST & 0.1237 & 0.2278 & 0.2808 & -0.1027 & 1.00 \\
\hline (*** denote significant at $1 \%, * *$ significant at $5 \%, *$ significant at $10 \%$ significance level)
\end{tabular}

Finally, the last one in Table 4 examined the potential determinants of bank CSR spending on the correlation analysis. The result of the correlation analysis reveals that profitability is a potential determinant of bank CSR spending. Both ROA and ROE positively correlated with bank CSR spending even though only ROE had a significant correlation with bank CSR spending. The results suggest that profitable banks invest more in the area of CSR as compared to less profitable ones. In other words, the more profitable a bank is, the more it will spend on CSR. 
The study's result is consistent with Sabri \& Sweiss (2016) findings, who also reported a positive and statistically significant coefficient between CSR and return on equity. The result also confirms previous studies such as Yeung (2011) and Nwaneri (2015), whom all reported a positive coefficient between CSR and firms' financial performance. A study of Indian banks revealed that only ROA, ROE, and EPS were influenced by CSR spending, which shows that the companies' key financials are affected if there is a change in CSR spending. The results also revealed a positive and statistically significant correlation between the bank's size and its CSR spending. The results suggest that larger banks spend more in the area of CSR as compared to smaller banks. According to Coffie et al. (2018), the size of a company and some other factors are important to CSR. It draws the community's attention towards urging these big companies to be socially responsible. In this case, there focus most of their CSR activities on attracting customers. Therefore, the bigger the firm size, the bigger CSR activities is carried out since it will also be another means of reaching out to customers.

On the other hand, the correlation results showed a negative and significant association between foreign ownership and bank CSR spending. The result shows that foreign banks spend less in the area of CSR as compared to local banks. Finally, the correlation results showed a positive and significant correlation between banks listed on the Ghana Stock Exchange and CSR expenditure. The results suggest that banks listed on the Ghana Stock exchange spend more on CSR than non-listed banks.

Marfo et al. (2016), in his study, found out that profitability does not have a significant influence on the level of voluntary CSR reporting by companies listed on the Ghana Stock Exchange, which means that spending on CSR is not dependent on the fact that a company is listed or not. Based on the results, the researcher also concludes that being listed on the Ghana Stock Exchange does not influence or associate with the disclosure of corporate social responsibility activities; hence, it does not affect CSR spending (Raynolds, 2015). According to Oppong (2014), CSR is less likely to be a key driver of investment decisions. As a result, CSR will not affect listed companies' financial performance, let alone unlisted ones due to underdeveloped stock exchange market such as GSE, thereby concluding that a bank listed or unlisted does not affect CSR spending.

Table 4. Correlation analysis of determinants of bank CSR spending

\begin{tabular}{lcrrrrr}
\hline & CSREXP & ROA & ROE & SIZE & OWN & \multicolumn{1}{c}{ LIST } \\
\hline CSREXP & 1.0000 & & & & & \\
ROA & 0.0363 & 1.0000 & & & & \\
ROE & $0.1593 * *$ & 0.4307 & 1.0000 & & & \\
SIZE & $0.4732 * *$ & 0.3085 & 0.2027 & 1.0000 & & \\
OWN & $-0.2294 * *$ & 0.1502 & 0.1146 & -0.0842 & 1.0000 & \\
LIST & $0.2278 * *$ & 0.0918 & 0.1237 & 0.2808 & -0.1027 & 1.0000 \\
\hline (*** denote significant at 1\%, ** significant at 5\%, * significant at 10\% significance level)
\end{tabular}

\section{Regression analysis}

Table 5 shows that the independent variables can explain $31 \%$ of the dependent variable's variations. The probability of the F-Statistic is significant, suggesting that the model is well fit. There is a positive relationship between bank CSR expenditure and bank profitability. However, the relationship is statistically insignificant. The results suggest that banks' CSR spending does not significantly improve profitability as measured by return on assets. The result is contrary to the first hypothesis's expectation, which expects a positive and significant association between bank CSR spending and profitability. The results suggest that customers do not reward banks for spending more 
on CSR, which could be attributed to several factors. This finding is consistent with the legitimacy theory's expectations, which sees CSR as a means to legitimize banks' operations and not for profit purposes.

On the control variables, bank size is positively associated with bank profitability (statistically significant at 1\%). The bigger banks enjoy economies of scale, which allows them to improve their profitability. The results are consistent with previous studies such as Musah (2018), Awnuyo-Vitor \& Badu (2012), and other similar studies in Ghana. Table 5 also revealed a positive association between the listing status of commercial banks and profitability. The banks listed on the Ghana Stock Exchange are more profitable than the non-listed banks. Finally, the relationship between foreign ownership bank profitability is statically insignificant.

Table 5. Regression results between ROA and independent variables

\begin{tabular}{lcc}
\hline Variable & Coefficient & Std. Err \\
\hline CSREXP & 0.0010303 & 0.0014459 \\
SIZE & $0.01348808^{* * *}$ & 0.0039016 \\
OWN & 0.0049425 & 0.0064400 \\
LIST & $0.08671^{* * *}$ & 0.0036375 \\
CONST. & $-0.0834328^{* *}$ & 0.0727922 \\
\hline R-Square & 0.3141 & \\
Wild Chi2 (4) & 13.8 & \\
Prob> Chi2 & 0.0095 & \\
(*** denote significant at 1\%, ** significant at 5\%, * significant at 10\% significance level)
\end{tabular}

Table 6 shows that there is a positive association (insignificant) between bank CSR spending and return on equity. This result is consistent with the legitimacy theory, which predicts an insignificant association between bank CSR and profitability. On the control variables, bank size is positively associated (significant) with return on equity.

The result confirms that larger banks can take a bigger risk and enjoy economies of scale, enhancing their profitability. The result also shows a positive association and significance between foreign ownership and return on equity. The result shows that foreign banks in Ghana generate greater returns to equity holders compared to local banks. Finally, the study found a positive association (insignificant) between commercial banks' listing status in Ghana and return on equity.

Table 6. Regression results between ROE and independent variables

\begin{tabular}{lcc}
\hline Variable & Coefficient & Std. Err \\
\hline CSREXP & 0.02060429 & 0.0208088 \\
SIZE & $0.1701048 * * *$ & 0.0600463 \\
OWN & $0.2056457 * *$ & 0.0811808 \\
LIST & 0.0656297 & 0.0851397 \\
CONST. & $-0.9417934^{*}$ & 0.5085073 \\
\hline R-Square & 0.4532 & \\
Wild Chi2 (4) & 11.33 & \\
Prob> Chi2 & 0.02 & \\
(*** denote significant at 1\%, ** significant at 5\%, * significant at 10\% significance level)
\end{tabular}

The analysis of bank CSR expenditure determinants shows a negative association between ROA and CSR spending. However, the relationship is statistically insignificant. The more profitable a bank, the less it spends on its CSR. In other words, profitable banks spend less on CSR in Ghana than less profitable ones using ROA to measure profitability. Contrary to the second hypothesis's expectations, the result predicts a positive association between bank profitability and CSR spending. 
Table 7 further revealed a negative association and significance between return on equity and profitability of commercial banks in Ghana. The result shows that banks with a higher return on equity spend more on CSR and vice versa. The result is consistent with the expectation of hypothesis $2 b$ and confirms the results of previous studies. In previous studies, like Naweiseh et al. (2015), more ROE companies are more likely to increase the extent of their corporate social disclosure, and less ROE companies are more likely to reduce the extent of their CSR disclosures about employees. The result also shows a positive and statistically significant association between bank size and CSR spending. The results show that larger banks spend more on CSR as compared to smaller banks.

Table 7. Regression results on determinants of bank CSR spending

\begin{tabular}{lcr}
\hline Variable & Coefficient & Std. Err \\
\hline ROA & -4.189033 & 3.966491 \\
ROE & $0.3527581^{* * *}$ & 0.1172208 \\
OWN & -0.5512974 & 0.4644785 \\
SIZE & $0.7561119^{* *}$ & 0.33606 \\
LIST & $0.6177136^{* * *}$ & 0.20888419 \\
CONST. & $5.372853 *$ & 2.891918 \\
\hline R-Square & 0.5614 & \\
Wild Chi2 (5) & 76.61 & \\
Prob> Chi2 & 0.000 & \\
\hline$* * *$ denote significant at 1\%, ** significant at 5\%, * significant at 10\% significance level)
\end{tabular}

The result is consistent with the expectation of legitimacy theory, which argues that larger corporations have huge exposure and will need to legitimize their operations by engaging in CSR. These larger banks spend more on CSR to enhance their corporate image, which is part of the legitimization process. The result is consistent with the expectations of hypothesis $\mathrm{H} 3$, which predicts a positive association between bank size and CSR expenditure and the legitimacy theory.

On the contrary, Naweiseh et al. (2015) discovered that evaluating the explanatory variables' slope coefficients reveals a negative relationship between the number of corporate social responsibility disclosures about employees and Firm Size at a significance level of 5\%. An analysis by Monsuru (2014) showed that the banks' size positively and significantly affects banks' profitability. The higher the expansion of banks' size, the higher the profitability of banks. The results revealed a negative association between foreign ownership and bank CSR expenditure on the issue of ownership. The relationship however, is statistically insignificant. The results suggest that foreign banks spend less in the area of CSR as compared to local indigenous Ghanaian banks.

Contrary to the legitimacy theory's expectations, foreign banks have greater responsibility in legitimization than local banks. Finally, the regression result shows a positive association between commercial banks' listing status and CSR expenditure. The result is statistically significant at $1 \%$ significance level. The result shows that banks listed on the Ghana Stock Exchange spend more on CSR than non-listed banks. The result is consistent with the expectations of the legitimacy theory and confirms the expectations of hypothesis H4. The result confirms the stakeholders' theory's expectations and assumes that listed firms have more stakeholders to address their concerns, increasing CSR expenditure. 


\section{CONCLUSION AND RECOMMENDATION}

\section{Conclusion}

Quite a reasonable amount of money is invested in doing CSR, which has also increased over the years. Also, engaging in CSR activities helps increase the banks' profitability both in ROE and ROA but more for ROE than ROA. Without the people of society, businesses cannot flourish, and without businesses, people in society cannot live comfortably. It is therefore wise for these two entities to be in a mutually benefiting relationship.

The listing status of commercial banks in Ghana has a lot to do with CSR activities and spending. The reason is that listed firms are considered bigger; therefore, the bigger the firm, the more likely it will be listed on the stock exchange. Since the study discovered that bigger firms engage more in CSR activities, listed firms are of no exemption. Therefore, the study concludes that bigger firms listed on the Ghana Stock Exchange engage more in CSR activities and spend more in that regard.

\section{Recommendation}

Government ensure that measures are put in place to ensure that all banks, listed or unlisted, foreign or local, big or small, should give back to society by engaging in CSR activities. This emphasis should be made strongly on foreign-owned banks since the study found that they do not engage more in CSR activities and spend relatively less on CSR.

\section{Limitations of the study}

One of the study's significant limitations is the reliance on secondary data as the primary source of data. The findings' validity is hinged on the secondary data's credibility extracted from the banks' annual reports. Given that almost all the data extracted were audited, it stands to reason that they are credible. Secondly, quantitative analysis through secondary data does not allow for netter introspection of the motives for banks' CSR spending, which can be improved through a qualitative study in the future. Finally, data unavailability did not allow some banks to be included in the study, enhancing the study's findings.

\section{REFERENCES}

Abukari, A. J., \& Abdul-Hamid, I. K. (2018). Corporate social responsibility reporting in the telecommunications sector in Ghana. International Journal of Corporate Social Responsibility, 3(2), 2.1-9

Aboagye-Otchere, F. K., Simpson, S. N. Y., \& Kusi, J. A. (2020). The influence of environmental performance on environmental disclosures: An empirical study in Ghana. Business Strategy \& Development, 3(1), 98-111.

Adeyanju, O. D. (2012). An assessment of the impact of corporate social responsibility on Nigerian society: The examples of banking and communication industries. Universal Journal of Marketing and Business Research, 1(1), 17-43.

Ahmed, S., \& Akter, M. (2015). Determinants of corporate social responsibility of banking industry listed in the Dhaka stock exchange limited. DU Journal of Marketing, 16, 1-16.

Al Mamun, M., Sohog, K., \& Akhter, A. (2013). A dynamic panel analysis of the financial determinants of CSR in Bangladeshi banking industry. Asian Economic and Financial Review, 3(5), 560.

Ansong, A. (2017). Corporate social responsibility and firm performance of Ghanaian SMEs: The role of stakeholder engagement. Cogent Business \& Management, 4(1), 1333704. 
Awunyo-Vitor, D., \& Badu, J. (2012). Capital structure and performance of listed banks in Ghana. Global Journal of Human-Social Science Research, 12(5).

Bhagawan, PM, \& Mukhopadhyay, J. P. (2018). Does Mandatory Expenditure on CSR Affect Firm Value? Empirical Evidence from Indian Firms. EFMA 2018 Meeting

Boateng, H., \& Abdul-Hamid, I. K. (2017). An evaluation of corporate social responsibility communication on the websites of telecommunication companies operating in Ghana. Journal of Information, Communication and Ethics in Society, 15(1), 17-31.

Bolton, B. J., Corporate Social Responsibility and Bank Performance (June 11, 2013). http://dx.doi.org/10.2139/ssrn.2277912.

Bowerman, S., \& Sharma, U. (2016). The effect of corporate social responsibility disclosures on share prices in Japan and the UK. Corporate Ownership and Control, 13(2), 202-216

Chauhan, S. (2014). A Relational Study of Firm's Characteristics and CSR Expenditure. Procedia Economics and Finance, 11, 23-32.

Cheng, B., Ioannou, I., \& Serafeim, G. (2014). Corporate social responsibility and access to finance. Strategic management journal, 35(1), 1-23.

Chih, H. L., Chih, H. H., \& Chen, T. Y. (2010). On the determinants of corporate social responsibility: International evidence on the financial industry. Journal of Business Ethics, 93(1), 115-135.

Coffie, W., Aboagye-Otchere, F., \& Musah, A. (2018). Corporate social responsibility disclosures (CSRD), corporate governance and the degree of multinational activities: Evidence from a developing economy. Journal of Accounting in Emerging Economies, 8(1), 106-123

Cornett, M. M., Erhemjamts, O., \& Tehranian, H. (2014). Corporate social responsibility and its impact on financial performance: Investigation of US commercial banks. Unpublished manuscript.

Cornett, M. M., Erhemjamts, O., \& Tehranian, H. (2016). Greed or good deeds: An examination of the relation between corporate social responsibility and the financial performance of US commercial banks around the financial crisis. Journal of Banking \& Finance, 70, 137-159.

Donaldson, T., \& Preston, L. E. (1995). The stakeholder theory of the corporation: Concepts, evidence, and implications. Academy of Management Review, 20(1), 6591.

Ebo Hinson, R., \& Kodua, P. (2012). Examining the marketing-corporate social responsibility nexus. International Journal of Law and Management, 54(5), 332344.

El Ghoul, S., Guedhami, O., Kwok, C. C., \& Mishra, D. R. (2011). Does corporate social responsibility affect the cost of capital?. Journal of Banking \& Finance, 35(9), 2388-2406.

Fifka, M. S. (2013). Corporate responsibility reporting and its determinants in comparative perspective - a review of the empirical literature and a metaanalysis. Business strategy and the environment, 22(1), 1-35.

Fijałkowska, J., Zyznarska-Dworczak, B., \& Garsztka, P. (2017). The relation between the CSR and the accounting information system data in Central and Eastern European (CEE) countries- the evidence of the Polish financial institutions. Accounting and Management Information Systems, 16(4), 490-521.

Freeman, R. E., \& Reed, D. L. (1983). Stockholders and stakeholders: A new perspective on corporate governance. California management review, 25(3), 88-106. 
Garcia-Castro, R., Ariño, M. A., \& Canela, M. A. (2010). Does social performance really lead to financial performance? Accounting for endogeneity. Journal of Business Ethics, 92(1), 107-126.

Griffin, J. J., \& Mahon, J. F. (1997). The corporate social performance and corporate financial performance debate: Twenty-five years of incomparable research. Business \& Society, 36(1), 5-31.

Hassn, N. T. (2014). Corporate governance, degree of multi-nationality, and corporate social responsibility disclosure: evidence from the UK. Journal of Empirical Research in Accounting \& Auditing, 1(1), 1-18.

Hinson, R., Boateng, R., \& Madichie, N. (2010). Corporate social responsibility activity reportage on bank websites in Ghana. International Journal of Bank Marketing, 28(7), 498-518.

Islam, Z., Ahmed, S., \& Hasan, I. (2013). Corporate social responsibility and financial performance linkage: Evidence from the banking sector of Bangladesh. Bank Prikrama, 48(2), 109-130

Lee, S., Seo, K., \& Sharma, A. (2013). Corporate social responsibility and firm performance in the airline industry: The moderating role of oil prices. Tourism management, 38, 20-30.

Mahmoud, M. A., Blankson, C., \& Hinson, R. E. (2017). Market orientation and corporate social responsibility: towards an integrated conceptual framework. International Journal of Corporate Social Responsibility, 2(1), 9.

Marcia, M. C., Otgontsetseg, E., \& Hassan, T. (2013). Corporate Social Responsibility and its Impact on Financial Performance: Investigation of US Commercial Banks. Unpublished research paper, Department of Finance, Bentley University, Waltham, US.

Marfo, E. O., Chen, L., Xuhua, H., \& Benjamin, G. (2016). The antecedents of corporate social responsibility for extractive industries in the governance systems in Africa. International Journal of Engineering Research in Africa, 24.

Margolis, J. D., \& Walsh, J. P. (2003). Misery loves companies: Rethinking social initiatives by business. Administrative science quarterly, 48(2), 268-305.

Mbithi, A. M. (2015). Effects of corporate social responsibility on organisations' profitability of the banks listed on Nairobi stock exchange [Doctoral dissertation]. South Eastern Kenya University

Musah, A., Abdulai, M., \& Baffour, H. (2019). The Effect of Mergers and Acquisitions on Bank Performance in Ghana. Asian Journal of Economics and Empirical Research, 7(1), 36-45.

Musah, A. (2018). The Impact of Capital Structure on Profitability of Commercial Banks in Ghana. Asian Journal of Economic Modelling, 6(1), 21-36.

Nwaneri, E. C. (2015). The impact of corporate social responsibility (CSR) on organization profitability. International Journal of Business and Management, 10(9), 60.

Ofori, D. F., \& Hinson, R. E. (2007). Corporate social responsibility (CSR) perspectives of leading firms in Ghana. Corporate Governance, 7(2), 178-193.

Ofori, D. F., S-Darko, M. D., \& Nyuur, R. B. (2014). Corporate social responsibility and financial performance: Fact or fiction? A look at Ghanaian banks. Acta Commercii, 14(1), 1-11.

Omoro, N., Kinyua, H., \& Okiro, K. (2013). Investment in Corporate Social Responsibility and Sustained Growth in Commercial Banks in Kenya. Journal of Emerging Issues in Economics, Finance and Banking. An Online International Monthly Journal, 3(2), 1057-1064. 
Oppong, S. (2014). Corporate Social Responsibility and Corporate Performance: A Study of the Top 100 Performing Firms in Ghana. Journal of Contemporary Research in Management, 9(2), 23-33

Orlitzky, M., Schmidt, F. L., \& Rynes, S. L. (2003). Corporate social and financial performance: A meta-analysis. Organization studies, 24(3), 403-441.

Rahaman, A.S. (2000). Senior management perceptions of social and environmental reporting in Ghana. Social and Environmental Accountability Journal, 20(1), 7-10.

Rahaman, A. S., Lawrence, S., \& Roper, J. (2004). Social and environmental reporting at the VRA: institutionalised legitimacy or legitimation crisis?. Critical Perspectives on Accounting, 15(1), 35-56.

Sabri, T. B. H., \& Sweis, K. M. H. (2016). Effect of Corporate Social Responsibility on Profitability of Banks Working in Palestine (Case Study 2013-2014). International Journal of Business Administration, 7(6), 107.

Samina, Q. S. (2012). Practice of corporate social responsibility in Islamic banks of Bangladesh. World, 2(6), 1-13.

Shen, C. H., \& Chang, Y. (2009). Ambition versus conscience, does corporate social responsibility pay off? The application of matching methods. Journal of Business Ethics, 88(1), 133-153.

Soana, M. G. (2011). Corporate social responsibility and financial performance: evidence from the financial sector. Corporate Ownership \& Control, 8(2), 27-36.

Sweeney, L. (2009). A study of current practice of corporate social responsibility (CSR) and an examination of the relationship between CSR and financial performance using structural equation modelling (SEM). [Doctoral Dissertation], Dublin Institute of Technology, Dublin

Tafti, S. F., Hosseini, S. F., \& Emami, S. A. (2012). Assessment the corporate social responsibility according to Islamic values (case study: Sarmayeh Bank). ProcediaSocial and Behavioral Sciences, 58, 1139-1148.

Taskin, D. (2015). The Relationship between CSR and Banks' Financial Performance: Evidence from Turkey. Journal of Yaşar University, 10(39), 21-30.

Weshah, S. R., Dahiyat, A. A., Awwad, M. R. A., \& Hajjat, E. S. (2012). The impact of adopting corporate social responsibility on corporate financial performance: Evidence from Jordanian banks. Interdisciplinary Journal of Contemporary Research in Business, 4(5), 34-44.

Wu, M. W., \& Shen, C. H. (2013). Corporate social responsibility in the banking industry: Motives and financial performance. Journal of Banking \& Finance, 37(9), 35293547.

Yeung, S. (2011). The role of banks in corporate social responsibility. Journal of Applied Economics and Business Research, 1(2), 103-115.

Welbeck, E. E., Owusu, G. M. Y., Bekoe, R. A., \& Kusi, J. A. (2017). Determinants of environmental disclosures of listed firms in Ghana. International Journal of Corporate Social Responsibility, 2(1), 11.

(C) 2020 by the authors. Licensee JPPD, Indonesia. This article is an open-access article distributed under the terms and conditions of the Creative Commons Attribution (CC BY) license (http://creativecommons.org/licenses/by/4.0/). 